\title{
A comparison of temporal variability of observed and model-based pan evaporation over Uruguay (1973-2014)
}

\author{
Sergio M. Vicente-Serrano ${ }^{1}$, Mario Bidegain ${ }^{2}$, Miquel Tomas-Burguera ${ }^{3}$, Fernando \\ $\underline{\text { Dominguez-Castro }}^{1}$, Ahmed El Kenawy ${ }^{1,4}$, Tim R. $\underline{\text { McVicar }}^{5}$, Cesar Azorin-Molina ${ }^{6}$, \\ Juan I. López-Moreno ${ }^{1}$, Raquel $\underline{\text { Nieto }}^{7}$, Luis $\underline{\text { Gimeno }}^{7}$ and Agustín Gimenez ${ }^{8}$ \\ (Family names or surnames are underlined) \\ ${ }^{1}$ Instituto Pirenaico de Ecología, Consejo Superior de Investigaciones Científicas (IPE- \\ CSIC), Spain \\ ${ }^{2}$ Instituto Uruguayo de Meteorología, Uruguay \\ ${ }^{3}$ Estación Experimental de Aula Dei (EEAD-CSIC), Spain \\ ${ }^{4}$ Department of Geography, Mansoura University, Mansoura, Egypt \\ ${ }^{5}$ CSIRO Land and Water, Australia \\ ${ }^{6}$ Regional Climate Group, Department of Earth Sciences, University of Gothenburg, \\ Sweden \\ ${ }^{7}$ Environmental Physics Laboratory, Universidade de Vigo, Spain \\ ${ }^{8}$ Instituto Nacional de Investigación Agropecuaria, GRASS.Uruguay
}

Abstract. This study analyzes variability and trends of atmospheric evaporative demand (AED) across Uruguay in the past four decades. Changes were assessed using pan evaporation measurements from 10 meteorological stations and compared to PenPan model calculations, which is a physically based model that employs meteorological data as input. Results demonstrate a high agreement between the observed AED and those estimated from the PenPan model. Both observations and model estimations agree on a high interannual variability in AED, though being statistically insignificant $(p>0.05)$ at seasonal and annual scales. Given that AED shows high sensitivity to changes in relative humidity and sunshine duration, as a surrogate of solar radiation, the lack of significant trends in the AED observations and estimations over Uruguay can be linked to the insignificant trend found for these climate variables for the period from 1973 to 2014. This is the first study that reports Pan evaporation trends for this part of the 
world, helping to infill gaps for mid-latitude southern hemisphere areas, which are poorly represented in Pan evaporation trends.

Key-words: Reference Evapotranspiration, Evaporation, Penman-Monteith, Uruguay, South America, Climate Change.

\section{Introduction}

Atmospheric evaporative demand (AED) is a key meteorological variable, with strong agronomic and hydrological impacts (Wang and Dickinson, 2012). AED is the maximum quantity of water that would evaporate from a surface under unlimited water availability and no-resistance factors from soil and vegetation (Katerji and Rana, 2011; such as pan evaporation and potential evaporation) or when resistance factors are not temporally varying (as is the case for FAO-56 crop reference evaporation). AED can be observed by pan evaporation and can be estimated using fully-physically based formulations of potential evaporation (Roderick et al. 2009; McVicar et al., 2012a and b). Following the seminal 'combination equation' work of Penman (1948) fullyphysically forms of potential evaporation are those that explicitly include the four main meteorological drivers of AED (i.e., air temperature, radiation, atmospheric humidity and wind speed) in their formulations to fully capture the AED responses of the radiative and aerodynamic components. The use of fully-physically based AED models has been widely advocated (e.g., Donohue et al 2010; McKenney and Rosenberg, 1993; McVicar et al 2012b; Roderick et al 2007). Given there are regional differences in the baseline climatologies and trends of air temperature (e.g., Jones et al., 2012), radiation (see Wild 2009 and the references therein), atmospheric humidity (e.g., Willett et al 2008; Durre et al 2009) and wind speed (see McVicar et al 2012b and the references therin) means some studies report increasing AED trends (e.g., Vicente-Serrano et al., 
2014a; Abtew et al., 2011; Tabari et al., 2012; Yu et al., 2016) while others report decreases AED trends (e.g., Peterson et al., 1995; Roderick and Farquhar, 2004. McVicar et al 2012a). The 'four-meteorological-variable / regionally-specific' framework to understand AED dynamics contrasts with the 'single-meteorologicalvariable / global' view that given global warming AED would increase by about $7 \%$ per $1^{\circ} \mathrm{C}$ according to the Clausius-Clapeyron relationship (due to the incremental capacity of air to store water under warming conditions). Implicit in the 'single-meteorologicalvariable / global' approach is the notion that only air temperature trends are large enough to impact AED; clearly not the case everywhere (see McVicar et al 2012b). This means when assessing AED dynamics the 'four-variable / regionally-specific' framework is required.

Few studies have compared temporal variability and trends in AED from pan evaporimeters and physically-based models (exceptions are Chattopadhyay and Hulme, 1997; Hobbins et al., 2004; Roderick et al 2007; Johnson and Sharma, 2007; Johnson and Sharma, 2010; Abtew et al., 2011; Azorin-Molina et al., 2015). As pan evaporimeter measurements are infrequent and uncertain in large regions of the world (Abtew et al., 2011), physically-based models can replicate AED observations, providing longer and homogeneous time series for assessing AED trends and variability. Nonetheless, given that the estimation of AED using physical models is based on different meteorological variables, it is possible to assess the role of each of these variables in the evolution and variability of AED.

In regions and countries whose economy depends heavily on agriculture, AED changes may have strong socioeconomic impacts. Positive trends of AED may increase plant 
respiration rates, actual evapotranspiration, plant water stress and ultimately xylem embolism, especially when soil water availability is not enough to supply the actual demand (McDowell et al., 2008). These impacts may also include a reduction/loss of crop yields, increase rates of forest drying and trigger forest fires. Even if the water availability is enough to supply the extra water required due to AED increases, it can affect the availability of water for other uses (e.g. the generation of electricity in hydroelectric plants, which is of key importance in Uruguay).

Uruguay is one of the countries with a higher percentage $(82.4 \%)$ of the territory covered by crops and forages to feed livestock (mainly cattle and sheep; http://www2.mgap.gub.uy/DieaAnterior/Anuario2015/DIEA-Anuario2015-01web.pdf; last access on 1st February 2017). Agriculture and livestock represent together more than $10 \%$ of the gross domestic product (GDP) of the country, contributing to more than $12 \%$ of the workforce and making Uruguay one of the main exporters of primary products (e.g. soybeans, wheat and rice) in the world. In Uruguay, climate variability and drought episodes cause drastic damages to the agricultural sector (Hareau et al., 1999; Grosskopf et al., 2015). A representative example is the severe drought in 2008, which caused an estimated loss of 450 million US dollars, which is equivalent to $1.5 \%$ of the Uruguanean GDP. Since high AED may increase drought severity impacts (Vicente-Serrano et al., 2014b; Hunt et al., 2014; Otkin et al., 2014), but also affect the severity of flood events via actual evapotranspiration and soil moisture conditions (Lana-Renault et al., 2014), assessing recent AED variability and changes in Uruguay deserves investigation. Also assessing AED trends is severly limited in mid-latitidue southern hemipshere and Pan evaporation trends are rare for South America (see 
107

108

109

110

McVicar et al., 2012b) where 422.5 million people live (2015 estimate; UN, 2015) and is projected to grow to 500 million people in 2050 (UN, 2015).

In this study, we analyzed variability and trends of the AED in Uruguay from 1973 to 2014 using pan evaporation measurements and calculations based on a fully-physically based model that employs meteorological data as input. The objectives of this study are to: (i) quantify and compare the temporal variability of the observed pan evaporation and those derived model estimations; (ii) detemine annual and seasonal AED trends; and (iii) to evaluate the contribution of each climatic variable in explaining AED variability in Uruguay.

\section{Data and methods}

We employed meteorological data from 10 observatories, provided by the Instituto Nacional de Investigación Agropecuaria (INIA) and the Instituto Uruguayo de Meteorología agrometeorological networks (INUMET) (Table 1). The earliest available agrometeorological station was established in 1973, while the last two stations were installed in 1991. Spatially, the meteorological stations are evenly distributed across the country, whose topography is very homogeneous, with an elevation lower than $300 \mathrm{~m}$ (Figure 1). Additionally, the spatial distribution of these stations is representative of the main climatic conditions across Uruguay, which are generally temperate, with rainfall evenly distributed across the whole year (Peel et al., 2007). Daily records of maximum and minimum air temperatures, relative humidity, wind speed, sunshine duration (used to estimate solar radiation following Allen et al., 1998) and Class-A pan evaporation were used. A maximum of 3 missing days per month was allowed to obtain mean monthly values of each meteorological variable. Otherwise, the entire month was set as 
missing. Overall, the available time series of the different variables were almost complete, with less than $10 \%$ of missing months for all stations over the variable-length study periods (as seen in Table 1).

The monthly series were checked carefully for quality assurance and homogenization. Following Vicente-Serrano et al. (2010), the quality control procedure compared the rank of each data record with the average rank of the monthly observations at the remaining 9 stations. We used a relative homogeneity method (HOMER HOMogenization software in R), which compares each candidate series with the rest of available series (Mestre et al., 2013). HOMER is a semi-automated methodology that combines a fully automatic joint segmentation with a partly subjective pairwise comparison. HOMER corrected the existing inhomogeneities and inserted missing monthly values using the method of Mestre et al. (2013; specifically their Equation (8)). Among the different existing models that estimate AED from meteorological data (e.g. Penman, 1948; Allen et al., 1998), we selected the PenPan model (Rotstayn et al., 2006), which coupled the radiative component of Linacre (1994) and the aerodynamic component of Thom et al. (1981). PenPan estimates monthly and annual Class-A pan evaporation. Previous studies indicated good agreement between Pan evaporation observations and PenPan calculations over Australia (Roderick et al., 2007; McMahon et al., 2013), China (Liu et al., 2011; Yang and Yang, 2012), US (Hobbins et al., 2012), India (Padmakunari et al., 2013), and Spain (Azorin-Molina et al., 2015).

According to Rotstayn et al. (2006), PenPan is defined as:

$$
E_{\text {PenPan }}=\frac{\Delta}{\Delta+2.4 \gamma} \frac{R_{N P a n}}{\lambda} f_{\text {Pan }}(u)\left(e_{s}-e_{a}\right)
$$


$156 f_{\text {Pan }}=1.202+1.62 u_{2}$ where EenPan is the pan evaporation $\left(\mathrm{mm} \mathrm{day}^{-1}\right)$ calculated by the

157 PenPan model, $\Delta$ is the slope of the vapour pressure curve $\left(\mathrm{kPa}^{\circ} \mathrm{C}^{-1}\right), \gamma$ is psychrometric constant $\left(\mathrm{kPa}^{\circ} \mathrm{C}^{-1}\right), \lambda$ is the latent heat of vaporization $\left(\mathrm{MJ} \mathrm{Kg}^{-1}\right), e_{s}-e_{a}$ is vapour pressure deficit $(\mathrm{kPa}), u_{2}$ is the average daily wind speed at $2 \mathrm{~m}$ height $\left(\mathrm{ms}^{-1}\right)$ and $R_{N \text { pan }}$ is the net radiation at the Class-A pan evaporimeters, whose calculation is provided in the Supplementary Material 6 of McMahon et al. (2013). Following this equation, we calculated PenPan evaporation using the meteorological data in each of the ten available stations across Uruguay.

Given the close location of the different meteorological stations and the low elevation differences between them, we created two series representing the observed Pan and modelled PenPan evaporation across Uruguay. Given the varying length of the series, we obtained the monthly series of the standardized anomalies for each series, with respect to a 1992-2014 reference period. The series of anomalies were averaged and transformed into evaporation units (in mm months ${ }^{-1}$ ) using the mean and the standard deviation for the 1992-2014 common period. Regional series for the input meteorological variables were then obtained according to the same approach implemented for Pan and PenPan evaporation.

To assess changes in seasonal and annual Pan and PenPan evaporation, as well as the input meteorological variables (e.g. relative humidity, air temperature, wind speed and sunshine duration), we used the nonparametric Mann-Kendall statistic. Autocorrelation was considered in the trend analysis applied to the different series and climatic variables. The modified Mann-Kendall trend test was used, which returns the corrected p-values after accounting for temporal pseudor replication (Hamed and Rao, 1998; Ye 
and Wang, 2004). To quantify the magnitude of change in Pan and PenPan, we used linear regression analysis between the series of time (independent variable) and the evaporation series (dependent variable). The slope of the regression measures the change per year. Finally, to account for the possible contribution of different climatic variables (i.e. relative humidity, mean air temperature, wind speed and sunshine duration) to the evolution of AED, we assessed the links between the seasonal and annual time series of observed Pan and modelled PenPan evaporation and those of the climatic variables using correlation analysis.

\section{Results}

\subsection{Spatial consistency of evaporation across Uruguay}

Figure 2 shows two density plots that illustrate the Pearson correlation coefficients between the annual and seasonal time series of Pan evaporation (Figure 2a) and PenPan evaporation (Figure 2b) recorded between all the different pairs of meteorological stations. As depicted, the correlations are generally positive and high among the stations, either for Pan observations or PenPan estimations. The only exception was found for the austral winter season (Jun-Jul-Aug), particularly for Pan evaporation. Similarly, the regional series calculated for the whole country show high agreement with the individual stations for both Pan observations and PenPan estimations (Figure 3). These results reinforce the robust utility of the regional series in the analysis.

\subsection{Temporal variability of evaporation in Uruguay}

Figure 4 reveals a strong agreement between the monthly regional Pan observations and PenPan estimations, calculated for the whole of Uruguay. The series show a similar interannual variability, with almost identical magnitudes. The agreement at the annual timescale is also revealed at the seasonal scale, where there is a high agreement between 
the regional Pan observations and PenPan estimations series for all seasons between 1973 and 2014 (Figure 5). Although PenPan generally shows higher values than Pan observations, both indicate close interannual variability. The correlation between Pan observations and PenPan estimations is high (>0.86) at the seasonal and annual timescales. The only exception is the austral winter, where the correlation did not exceed 0.78 , though being statistically significant at the $95 \%$ confidence level. Note: due to the low contribution of winter to the total annual evaporation, the lower winter correlation did not adversely impact the annual timescale correlation $(\mathrm{r}=0.89)$. The strong relationship found with the regional series is also recorded at the individual stations (Table 2). Although our analysis covers different periods as a function of the availability of meteorological data at each station, the correlations were strong and statistically significant $(\mathrm{p}<0.05)$, particularly during the austral summer (Dec-Jan-Feb).

Overall, the nationwide regional series did not show statistically significant trends over the whole period (1973-2014) either for Pan observations or PenPan estimations; however, PenPan significantly increased during summer and annually when considering the 1992-2014 reference period (Table 3). In contrast, this significant increase was not observed for the Pan observations regional series. Trends in individual stations did not reveal any clear pattern, with the exception of two INUMET stations (Treinta y tres and Tacuarembo), which exhibited dominant negative and positive trends for Pan observations and PenPan estimations, respectively. The statistically insignificant ( $p>0.05)$ trends dominated in the remaining stations across Uruguay.

\subsection{Relationship with driving meteorological variables}


231 Similar to Pan observations and PenPan estimations, seasonal and annual evolution of

232 the meteorological variables did not show any noticeable trends between 1973 and 2014

233 (Figure 6 and Table 4). Results reveal a moderate increase in minimum air temperature,

234 which is statistically significant $(\mathrm{p}<0.05)$ during spring and annually. Annual relative

235 humidity showed a dominant insignificant decrease, which was statistically significant

236 only in summer. There were no noticeable changes in the annual and seasonal series of

237 wind speed and sunshine duration.

238

The lack of significant trends in the analyzed meteorological variables is consistent with the observed changes in Pan observations and PenPan estimations, confirming that these four variables strongly determine the interannual variability of both observed and estimated AED. Figures 7 and 8 illustrate the relationship between annual and seasonal regional series of Pan observations and PenPan estimations and the different regional meteorological variables. The relationships are quite similar considering both the observed Pan and modelled PenPan evaporation series. As depicted, maximum air temperature was positively correlated with Pan and PenPan evaporation at seasonal and annual scales. In contrast, minimum air temperature showed negative correlations with all variables, albeit with statistically insignificant levels. In comparison to other analyzed variables, relative humidity exhibited the strongest correlations with Pan and PenPan evaporation series at the annual and seasonal scales, mainly with statistically significant $(\mathrm{p}<0.05)$ negative correlations. Results also indicate small differences in the magnitude of correlations between Pan and PenPan evaporation. Wind speed showed a positive correlation with Pan and PenPan evaporation, though being statistically significant only in summer and annually. Sunshine duration also exhibited positive and statistically significant associations with both Pan and PenPan evaporation; the 
strongest correlations were found annually and seasonally. As expected, we found very

257 few differences when analyzing the series for the individual stations (Tables 5 and 6),

258

259

262

263

264

265

266

267

268

269

270

271

272

stressing a similar behavior for both Pan observations and PenPan estimations. The relative humidity, sunshine duration and maximum air temperature (in this rank) are the variables that better explain the interannual variability of AED across Uruguay over the past four decades.

\section{Discussion and conclusion}

We present the first analysis of AED variability and trends based on Pan evaporation observations in Uruguay, southern South America. This study has analyzed recent variability and trends in AED over Uruguay using Class-A pan evaporation measurements and estimations by means of a physical model that uses meteorological variables as input. The high agreement found between AED observations and estimations over Uruguay agrees well with the results reported earlier for other regions of the world (e.g. Cohen et al., 2002; Xu et al., 2006; Zhang et al., 2007; Roderick et al 2007; Azorin-Molina et al., 2015). This agreement stresses the capacity of using physical methods for estimating long-term variability and trends in AED. In this context, although some input variables in these physical models are scarce and usually inhomogeneous (e.g. relative humidity, wind speed, and sunshine duration), they are measured much more frequently than Pan evaporation.

For the series analysed here, AED shows a high interannual variability, albeit with statistically insignificant trends at seasonal and annual scales. This result was also obtained using AED rates estimated using the PenPan model. The general results obtained based on the nationwide regional series of Uruguay concur with those found 
281 for the individual 10 meteorological stations employed in this work, suggesting non-

282

283

284

285

286

287

288

289

290

291

292

293

294

295

296

297

298

299

300

301

302

303

304 noticeable changes in the AED during 1973-2014.

It is difficult to establish regional comparisons with the observed trends in AED found for Uruguay, given that very few studies have analyzed this issue in southern South America. De la Casa and Avando (2016) analyzed crop reference evapotranspiration $\left(\mathrm{ET}_{\mathrm{o}}\right)$ variability and trends in central Argentina between 1941 and 2010 using Allen et al. (1998). Although covering a longer period, the Argentinan results of De la Casa and Avando (2016) resemble those of Uruguay, with no significant changes in $\mathrm{ET}_{\mathrm{o}}$ evolution. They attributed this pattern to the notion that climate variables that determine AED observed in central Argentina have shown insignificant changes. Thus, they indicated that, over the second half of the $20^{\text {th }}$ century, only $10 \%, 18 \%$ and $6 \%$ of the central Argentina region exhibited significant changes $(p<0.05)$ in air temperature, relative humidity and wind speed, respectively.

Similar to Argentina, the lack of significant trends in AED observations and estimations over Uruguay can be linked to the insignificant trends found for surface climate variables for 1973-2014. In particular, significant trends $(\mathrm{p}<0.05)$ are only found for spring maximum air temperature, annual and spring minimum air temperature (positive) and summer relative humidity (negative). Thus, the temperature series series in Uruguay do not show the dominant pattern found at the global scale, characterised by accelerated warming from 1970s to 2000s and hiatus periods from 2000s (e.g., Cahil et al., 2015; Trenberth, 2015). 
305

306

307

308

The studies on trends in surface climate variables in La Plata basin, albeit with longer periods than our study, demonstrate dominant insignificant trends. For example, Ricardo Barros et al. (2015) suggested a warming trend in Argentina of $+0.04{ }^{\circ} \mathrm{C}$ decade $^{-1}$, which is lower than the global terrestrial average of $+0.065^{\circ} \mathrm{C}$ decade $^{-1}$ during the $20^{\text {th }}$ century (Hartmann et al., 2013). Other studies suggest an opposite trend over the same region. Nuñez et al. (2008) revealed no significant trends in the mean air temperature across Argentina for 1961-2008. Maximum air temperature exhibited a dominant decrease in La Plata basin during the past decades, while a significant increase was only recorded for minimum air temperature (Rusticucci and Barrucand, 2004; Rusticucci and Renom, 2008; Rusticucci, 2012; Tencer and Rusticucci, 2012; Skansi et al., 2013; Marengo and Camargo, 2008). The higher warming trends for minimum than maximum air temperature agree with our results obtained for Uruguay during 19732014. Nevertheless, AED variability is not a consequence of the variability of minimum air temperature alone, as correlations were dominantly insignificant in the majority of meteorological stations and seasons of the year. Although AED showed more sensitivity to maximum air temperature in Uruguay, it exhibited no significant changes during the analyzed period. Similar to maximum air temperature, AED showed high response to interannual variability in relative humidity and sunshine duration; these variables also did not show any significant trends over Uruguay. Likewise, sunshine duration almost showed a steady evolution in southern South America during the past four decades (Raichijk, 2012) also in opposition to the dominant dimming and brightening periods recorded in the last decades globally (Wild, 2012).

Although no significant trends were recorded for the AED series of Uruguay, a strong interannual variability was recorded both at seasonal and annual scales. This strong 
interannual variability can probably be linked to the influence of different atmospheric circulation patterns like the ENSO, which strongly controls air temperature, precipitation and cloudiness in the region (e.g. Rosenbluth et al., 1997; Rusticucci and Vargas, 2002; Marengo and Camargo, 2008; Rusticucci et al., 2016). In Uruguay, Rusticucci and Renom (2008) demonstrated that air temperature extremes have strong correlation with the Pacific Sea Surface Temperature (SST). Nonetheless, other mechanisms may also affect climate variability in the region, including the frequency of blocking high pressure systems (Alessandro, 2014), changes in the mean regional Hadley circulation (Freitas and Ambrizzi, 2015), the existence of barotropic anticyclonic anomalies in the Southern Atlantic and low pressure centers over South America and the Southern Annular mode (Renom et al., 2011; Rusticucci et al., 2003). Accordingly, further research to define the atmospheric mechanisms responsible for the variability and changes of AED in the region should be conducted.

Although our study has shown no generalized significant trends in the climate conditions over Uruguay for 1973-2014, which explain the lack of significant trends of AED, the most recent climate change models predict a strong air temperature increase in the region at the end of the $21^{\text {st }}$ century. Over La Plata basin, Barros et al. (2015) indicated that average air temperature may increase by $3.5^{\circ} \mathrm{C}$ at the end of this century. If all other meteorological variables remained constant through time, this warming trend could increase future regional AED, which would reinforce the severity of climate droughts associated with decreased and more temporally variable precipitation (Reboita et al., 2014; Cabré et al., 2016). However, to fully understand AED dynamics from a process perspective and recalling the previously introduced 'four-meteorologicalvariable / regionally-specific' framework (compared to the 'single-meteorological- 
variable / global' view) we strongly recommend that future climate change models need to assess changes in all variables governing the AED process. Recalling the general vulnerability of the primary sector and the overall economy of Uruguay to climate variability (Hareau et al., 1999; Wagner et al., 2013; Bucaram et al., 2016), it is highly probable that increased AED would reinforce negative impacts of climatic change in the region.

\section{Acknowledgements}

This work was supported by the by the EPhysLab (UVIGO-CSIC Associated Unit) and research projects I-Link1001 financed by CSIC, PCIN-2015-220, CGL2014-52135C03-01, Red de variabilidad y cambio climático RECLIM (CGL2014-517221-REDT) financed by the Spanish Commission of Science and Technology and FEDER, and IMDROFLOOD financed by the Water Works 2014 co-funded call of the European Commission. Our thanks extend to the Instituto Uruguayo de Meteorologia (INUMET) and Instituto Nacional de Investigacion Agropecuaria de Uruguay (INIA) for their invaluable contribution. We thank the two anonymous reviewers and editor for helpful comments.

\section{References}

Abtew W, Obeysekera J, Iricanin N. 2011. Pan evaporation and potential evapotranspiration trends in South Florida. Hydrol. Process. 25: 958-969.

Allen RG, Pereira LS, Raes D, Smith M. 1998. Crop Evapotranspiration - Guidelines for Computing Crop Water Requirements - FAO Irrigation and Drainage Paper 56. <http://www.fao.org/docrep/x0490e/x0490e00.htm>

Azorin-Molina C, Vicente-Serrano SM, Sanchez-Lorenzo A, McVicar TR, MoránTejeda E, Revuelto J, El Kenawy A, Martín-Hernández N, Tomas-Burguera M. 2015. Atmospheric evaporative demand observations, estimates and driving factors in Spain (1961-2011). Journal of Hydrology 523: 262-277.

Alessandro AP. 2014. Incidence and trend of blocking action situations on the temperature and precipitation in Argentina. Atmosfera 27: 141-163.

Barros VR, Boninsegna JA, Camilloni IA, Chidiak M, Magrín GO, Rusticucci M. 2015. Climate change in Argentina: trends, projections, impacts and adaptation. WIREs Clim Change 6: 151-169.

Bucaram S, Fernández M, Renteria W. 2016. Assessing Local Vulnerability to Climate Change in Rio de la Plata Basin, Uruguay. Cuadernos de Economía y Administración 3: 1-19.

Cabré MF, Solman S, Núñez M. 2016. Regional climate change scenarios over southern South America for future climate (2080-2099) using the MM5 Model. Mean, interannual variability and uncertainties. Atmosfera 29: 35-60. 
Cahill N, Rahmstorf S, Parnell AC. 2015. Change points of global temperature. Environmental Research Letters 10: 084002. doi:10.1088/17489326/10/8/084002.

Chattopadhyay N, Hulme M. 1997. Evaporation and potential evapotranspiration in India under conditions of recent and future climate change. Agric. For. Meteorol. 87: 55-73.

Cohen S, Ianetz A, Stanhill G. 2002. Evaporative climate changes at Bet Dagan, Israel, 1964-1998. Agric. For. Meteorol. 111: 83-91.

De la Casa AC, Ovando GG. 2016. Variation of reference evapotranspiration in the central region of Argentina between 1941 and 2010. Journal of Hidrology: Regional Studies 5: 66-79.

Donohue RJ, McVicar TR, Roderick ML. 2010. Assessing the ability of potential evaporation formulations to capture the dynamics in evaporative demand within a changing climate. J. Hydrol. 386: 186-197.

Durre I, Williams Jr, CN, Yin X, Vose RS. 2009. Radiosonde-based trends in precipitable water over the northern hemisphere: an update. Journal of Geophysical Research Atmospheres 114: D05112. doi:10.1029/2008JD010989.

Freitas ACV, Ambrizzi T. 2015. Recent Changes in the Annual Mean Regional Hadley Circulation and Their Impacts on South America. Advances in Meteorology, 2015: 780205.

Grosskopf HM, Tourrand JF, Bartaburu D. et al. 2015. Use of simulations to enhance knowledge integration and livestock producers' adaptation to variability in the climate in northern Uruguay. Rangeland Journal 37: 425-432.

Hartmann DL, Klein Tank AM, Rusticucci M. 2013. Observations: Atmosphere and Surface. In: Climate Change 2013: The Physical Science Basis. Contribution of Working Group I to the Fifth Assessment Report of the Intergovernmental Panel on Climate Change [Stocker, T.F., D. Qin, G.-K. Plattner, M. Tignor, S.K. Allen, J. Boschung, A. Nauels, Y. Xia, V. Bex and P.M. Midgley (eds.)]. Cambridge University Press, Cambridge, United Kingdom and New York, NY, USA.

Hamed KH, Rao AR. 1998. A modified Mann Kendall trend test for autocorrelated data, J. Hydrol. 204: 182-196.

Hareau A, Hofstadter R, Saizar A. 1999. Vulnerability to climate change in Uruguay: Potential impacts on the agricultural and coastal resource sectors and response capabilities. Climate Research 12: 185-193.

Hobbins MT, Ramírez JA, Brown TC. 2004. Trends in pan evaporation and actual evapotranspiration across the conterminous U.S.: paradoxical or complementary? Geophys. Res. Lett. 31: L13503. http://dx.doi.org/10.1029/2004GL019846.

Hobbins M, Wood A, Streubel D, Werner K. 2012. What drives the variability of evaporative demand across the conterminous United States? J. Hydrometeorol. 13: $1195-1214$.

Hunt ED, Svoboda M, Wardlow B et al. 2014. Monitoring the effects of rapid onset of drought on non-irrigated maize with agronomic data and climate-based drought indices. Agricultural and Forest Meteorology 191: 1-11.

Jhajharia D, Kumar R, Dabral PP, Singh VP, Choudhary RR, Dinpashoh Y. 2014. Reference evapotranspiration under changing climate over the Thar Desert in India. Meteorol. Appl. 22: 425-435. 
Johnson F, Sharma A. 2007. Estimating evaporation - issues and challenges. In: MODSIM07 - Land, Water and Environmental Management: Integrated Systems for Sustainability, Proceedings, pp. 589-595.

Johnson F, Sharma A. 2010. A comparison of Australian open water body evaporation trends for current and future climates estimated fromclass a evaporation pans and general circulation models. J. Hydrometeorol. 11: 105-121.

Jones PD, Lister DH, Osborn TJ, Harpham C, Salmon M, Morice CP. 2012 Hemispheric and large-scale land-surface air temperature variations: An extensive revision and an update to 2010. Journal of Geophysical Research, 117: DOI: $10.1029 / 2011$ JD017139.

Katerji N, Rana G. 2011. Crop Reference Evapotranspiration: A Discussion of the Concept, Analysis of the Process and Validation. Water Resources Management 25: $1581-1600$.

Lana-Renault N, Nadal-Romero E, Serrano-Muela MP et al. 2014. Comparative analysis of the response of various land covers to an exceptional rainfall event in the central Spanish Pyrenees, October 2012. Earth Surface Processes and Landforms 39: 581-592.

Linacre ET. 1994. Estimating US Class A pan evaporation from few climate data. Water Int. 19: 5-14.

Liu X, Luo Y, Zhang D, Zhang M, Liu C. 2011. Recent changes in pan-evaporation dynamics in China. Geophys. Res. Lett. 38: L13404. http://dx.doi.org/ 10.1029/2011GL047929.

Liu T, Li L, Lai J, Liu C, Zhuang W. 2016. Reference evapotranspiration change and its sensitivity to climate variables in southwest China. Theor. Appl. Climatol. 125: 499.

Marengo JA, Camargo CC. 2008. Surface air temperature trends in Southern Brazil for 1960-2002. International Journal of Climatology 28: 893-904.

McDowell N. et al. 2008. Mechanisms of plant survival and mortality during drought: Why do some plants survive while others succumb to drought? New Phytol 178: 719-739.

McKenney MS, Rosenberg NJ. 1993. Sensitivity of some potential evapotranspiration estimation methods to climate change. Agric. For. Meteorol. 64: 81-110.

McMahon TA, Peel MC, Lowe L, Srikanthan R, McVicar TR. 2013. Estimating actual, potential, reference crop and pan evaporation using standard meteorological data: a pragmatic synthesis. Hydrol. Earth Syst. Sci. 17: 1331-1363.

McVicar TR, Roderick, M.L., Donohue, R.J., Van Niel, T.G., (2012a): Less bluster ahead? ecohydrological implications of global trends of terrestrial near-surface wind speeds. Ecohydrology 5 (4), 381-388.

McVicar, TR, Roderick ML, Donohue RJ et al. 2012b. Global review and synthesis of trends in observed terrestrial near-surface wind speeds: implications for evaporation. J. Hydrol. 416-417: 182-205.

Mestre O, Domonkos P, Picard F, Auer I, Robin S, Lebarbier E, Böhm R, Aguilar E, Guijarro J, Vertacnik G, Klancar M, Dubuisson B, Stepanek P. 2013. HOMER: HOMogenisation softwarE in R-methods and applications. Idöjárás 117: 47-67.

Nuñez MN, Ciapessoni HH, Rolla A, Kalnay E, Cai M. 2008. Impact of land use and precipitation changes on surface temperature trends in Argentina. Journal of Geophysical Research Atmospheres 113: D06111. 
Otkin JA, Anderson MC, Hain C, Svoboda M. 2014. Examining the relationship between drought development and rapid changes in the evaporative stress index. Journal of Hydrometeorology 15: 938-956.

Padmakumari B, Jaswal AK, Goswami BN. 2013. Decrease in evaporation over the Indian monsoon region: Implication on regional hydrological cycle. Climatic Change 121: 787-799.

Peel MC, Finlayson BL, McMahon TA. 2007. Updated world map of the KöppenGeiger climate classification, Hydrol. Earth Syst. Sci. 11: 1633-1644.

Penman HL. 1948. Natural evaporation from open water, bare soil and grass. Proc. Roy. Soc. London A 194: 120-145.

Peterson TC, Golubev VS, Groisman PY. 1995. Evaporation losing its strength. Nature 377: 687-688.

Raichijk C. 2012. Observed trends in sunshine duration over South America. International Journal of Climatology 32: 669-680.

Reboita MS, Da Rocha RP, Dias CG, Ynoue RY. 2014. Climate projections for South America: RegCM3 driven by HadCM3 and ECHAM5. Advances in Meteorology 2014: 376738

Renom M, Rusticucci M, Barreiro M. 2011. Multidecadal changes in the relationship between extreme temperature events in Uruguay and the general atmospheric circulation. Climate Dynamics 37: 2471-2480.

Roderick ML, Farquhar GD. 2004. Changes in Australian pan evaporation from 1970 to 2002. Int. J. Climatol. 24: 1077-1090.

Roderick ML, Rotstayn LD, Farquhar GD, Hobbins MT. 2007. On the attribution of changing pan evaporation. Geophys. Res. Lett. 34: L17403. http://dx.doi.org/10.1029/2007GL031166.

Roderick ML, Hobbins MT, Farquhar GD. 2009. Pan evaporation trends and the terrestrial water balance II. Energy balance and interpretation. Geography Compass 3: 761-780.

Rosenblúth B, Fuenzalida HA, Aceituno P. 1997. Recent temperature variations in southern South America. International Journal of Climatology 17: 67-85.

Rotstayn LD, Roderick ML, Farquhar GD. 2006. A simple pan-evaporation model for analysis of climate simulations: evaluation over Australia. Geophys. Res. Lett. 33: L17715. http://dx.doi.org/10.1029/2006GL027114.

Rusticucci M, Barrucand M. 2004. Observed trends and changes in Temperature Extremes over Argentina. J Climate 17: 4099-4107.

Rusticucci M, Vargas W. 2002. Cold and warm events over Argentina and their relationship with the ENSO phases: Risk evaluation analysis. International Journal of Climatology 22: 467-483.

Rusticucci M, Barrucand M, Collazo S. 2016. Temperature extremes in the Argentina central region and their monthly relationship with the mean circulation and ENSO phases. International Journal of Climatology 37: 3003-3017.

Rusticucci MM, Venegas SA, Vargas WM. 2003. Warm and cold events in Argentina and their relationship with South Atlantic and South Pacific Sea surface temperatures. Journal of Geophysical Research C: Oceans 108: 10.1029/2003JC001793.

Rusticucci M, Renom M. 2008. Variability and trends in indices of quality-controlled daily temperature extremes in Uruguay. International Journal of Climatology 28: 1083-1095. 
Rusticucci M. 2012. Observed and simulated variability of extreme temperature events over South America. Atmospheric Research 106: 1-17.

Skansi MDLM, Brunet M, Sigró J et al. 2013. Warming and wetting signals emerging from analysis of changes in climate extreme indices over South America. Global and Planetary Change 100: 295-307.

Tabari H, Aeini A, Talaee PH, Some'e BS. 2012. Spatial distribution and temporal variation of reference evapotranspiration in arid and semi-arid regions of Iran. Hydrological Processes 26: 500-512

Tencer B, Rusticucci M. 2012. Analysis of interdecadal variability of temperature extreme events in Argentina applying EVT. Atmosfera 25: 327-337.

Trenberth KE 2015. Has there been a hiatus? Internal climate variability masks climatewarming trends. Science 349: 691-692.

Thom AS, Thony J-L, Vauclin M. 1981. On the proper employment of evaporation pans and atmometers in estimating potential transpiration. Q. J. R. Meteorol. Soc. 107: 711-736.

UN. 2015. World Population Prospects: The 2015 Revision - Key Findings and Advance Tables. United Nations Department of Economic and Social Affairs, Population Division.

Vicente-Serrano SM, Beguería S, López-Moreno JI, García-Vera MA, Stepanek P. 2010. A complete daily precipitation database for North-East Spain: reconstruction, quality control and homogeneity. International Journal of Climatology 30: 1146-1163.

Vicente-Serrano SM, Azorin-Molina C., Sanchez-Lorenzo A. et al. 2014a. Reference evapotranspiration variability and trends in Spain, 1961-2011. Global and Planetary Change 121: 26-40.

Vicente-Serrano SM, Lopez-Moreno, J.I., Beguería, S. 2014b. Evidence of increasing drought severity caused by temperature rise in southern Europe. Environmental Research Letters 9 : 044001. doi:10.1088/1748-9326/9/4/044001

Wagner APL, Fontana DC, Fraisse C, Weber EJ, Hasenack H. 2013. Temporal trends of vegetation indices on Pampa grasslands in Brazil and Uruguay. Pesquisa Agropecuaria Brasileira 48: 1192-1200.

Wang K, Dickinson RE. 2012. A review of global terrestrial evapotranspiration: observation, modeling, climatology, and climatic variability. Rev. Geophys. 50: RG2005, doi:10.1029/2011RG000373.

Wild M, 2009. Global dimming and brightening: a review. Journal of Geophysical Research-Atmospheres 114: D00D16. doi:10.1029/2008JD011470.

Wild, M. 2012. Enlightening global dimming and brightening. Bulletin of the American Meteorological Society 93: 27-37.

Willett KM, Jones PD, Gillett NP, Thorne PW. 2008. Recent Changes in surface humidity: development of the HadCRUH dataset. Journal of Climate 21: 53645383.

Xu C., Gong L, Jiang T, Chen D, Singh VP 2006. Analysis of spatial distribution and temporal trend of reference evapotranspiration and pan evaporation in Changiiang (Yangtze River) catchment. Journal of Hydrology 327: 81-93.

Yang H, Yang D. 2012. Climatic factors influencing changing pan evaporation across China from 1961 to 2001. J. Hydrol. 414-415: 184-193.

Yue S, Wang C. 2004. The Mann-Kendall Test Modified by Effective Sample Size to Detect Trend in Serially Correlated Hydrological Series. Water Resour. Manage. 18: $201-218$. 
$587 \mathrm{Yu} \mathrm{W}$, Wu T, Wang W, Zhu X. 2016. Spatio temporal Changes of Reference Evapotranspiration in Mongolia during 1980-2006. Advances in Meteorology 2016: 9586896.

Zhang Y, Liu C, Tang Y, Yang Y. 2007. Trends in pan evaporation and reference and actual evapotranspiration across the Tibetan Plateau, J. Geophys. Res.-Atmos: 112, D12110, doi:10.1029/2006JD008161.

593 
Table 1: Main characteristics of the ten meteorological stations.

\begin{tabular}{|l|c|c|c|c|}
\hline \multicolumn{1}{|c|}{ (Network - Station) } & $\begin{array}{l}\text { Elevation } \\
\text { (meter) }\end{array}$ & Longitude & Latitude & \multicolumn{1}{l|}{ Period } \\
\hline INIA - TREINTA Y TRES & 46 & -54.43 & -33.26 & $1973-2014$ \\
\hline INIA - TACUAREMBO & 134 & -55.98 & -31.74 & $1987-2014$ \\
\hline INIA - SALTO GRANDE & 46 & -57.89 & -31.27 & $1984-2014$ \\
\hline INIA - LA ESTANZUELA & 20 & -57.69 & -34.34 & $1977-2014$ \\
\hline INIA - LAS BRUJAS & 41 & -56.34 & -34.67 & $1974-2004$ \\
\hline INUMET- ROCHA & 20 & -54.31 & -34.49 & $1985-2014$ \\
\hline INUMET- TREINTA Y TRES & 46 & -54.39 & -33.22 & $1988-2014$ \\
\hline INUMET - MERCEDES & 62 & -58.07 & -33.25 & $1991-2014$ \\
\hline INUMET - TACUAREMBO & 134 & -55.99 & -31.71 & $1991-2014$ \\
\hline INUMET- SALTO & 56 & -57.98 & -31.44 & $1985-2014$ \\
\hline
\end{tabular}


600

601

602
Table 2: Seasonal and annual Pearson's $r$ correlations between Pan and PenPan evaporation series for each meteorological station. Significant correlations at $p<0.05$ are bolded.

\begin{tabular}{|c|c|c|c|c|c|}
\hline & Annual & Summer (DJF) & Autumn (MAM) & Winter (JJA) & Spring (SON) \\
\hline INIA-TREINTA Y TRES & 0.82 & 0.91 & 0.79 & 0.60 & 0.71 \\
\hline INIA-TACUAREMBO & 0.80 & 0.84 & 0.87 & 0.71 & 0.74 \\
\hline INIA-SALTO GRANDE & 0.89 & 0.91 & 0.91 & 0.77 & 0.81 \\
\hline INIA-LA ESTANZUELA & 0.77 & 0.89 & 0.79 & 0.61 & 0.72 \\
\hline INIA-LAS BRUJAS & 0.78 & 0.84 & 0.73 & 0.61 & 0.75 \\
\hline INUMET-ROCHA & 0.70 & 0.86 & 0.62 & 0.30 & 0.60 \\
\hline $\begin{array}{l}\text { INUMET-TREINTA Y } \\
\text { TRES }\end{array}$ & 0.63 & 0.73 & 0.70 & 0.50 & 0.56 \\
\hline INUMET-MERCEDES & 0.67 & 0.81 & 0.93 & 0.14 & 0.55 \\
\hline $\begin{array}{l}\text { INUMET- } \\
\text { TACUAREMBO }\end{array}$ & 0.61 & 0.81 & 0.75 & 0.31 & 0.59 \\
\hline INUMET-SALTO & 0.85 & 0.90 & 0.82 & 0.73 & 0.73 \\
\hline
\end{tabular}


Table 3: Seasonal and annual trends in Pan observations and PenPan estimations corresponding to each meteorological station for the available period of data and for the common period (1992-2014). Only significant correlations at $\mathrm{p}<0.05$ are shown in bold. Annual trends have units of $\mathrm{mm} /$ year/available period, and seasonal trends have units of $\mathrm{mm} / \mathrm{season} /$ available period.

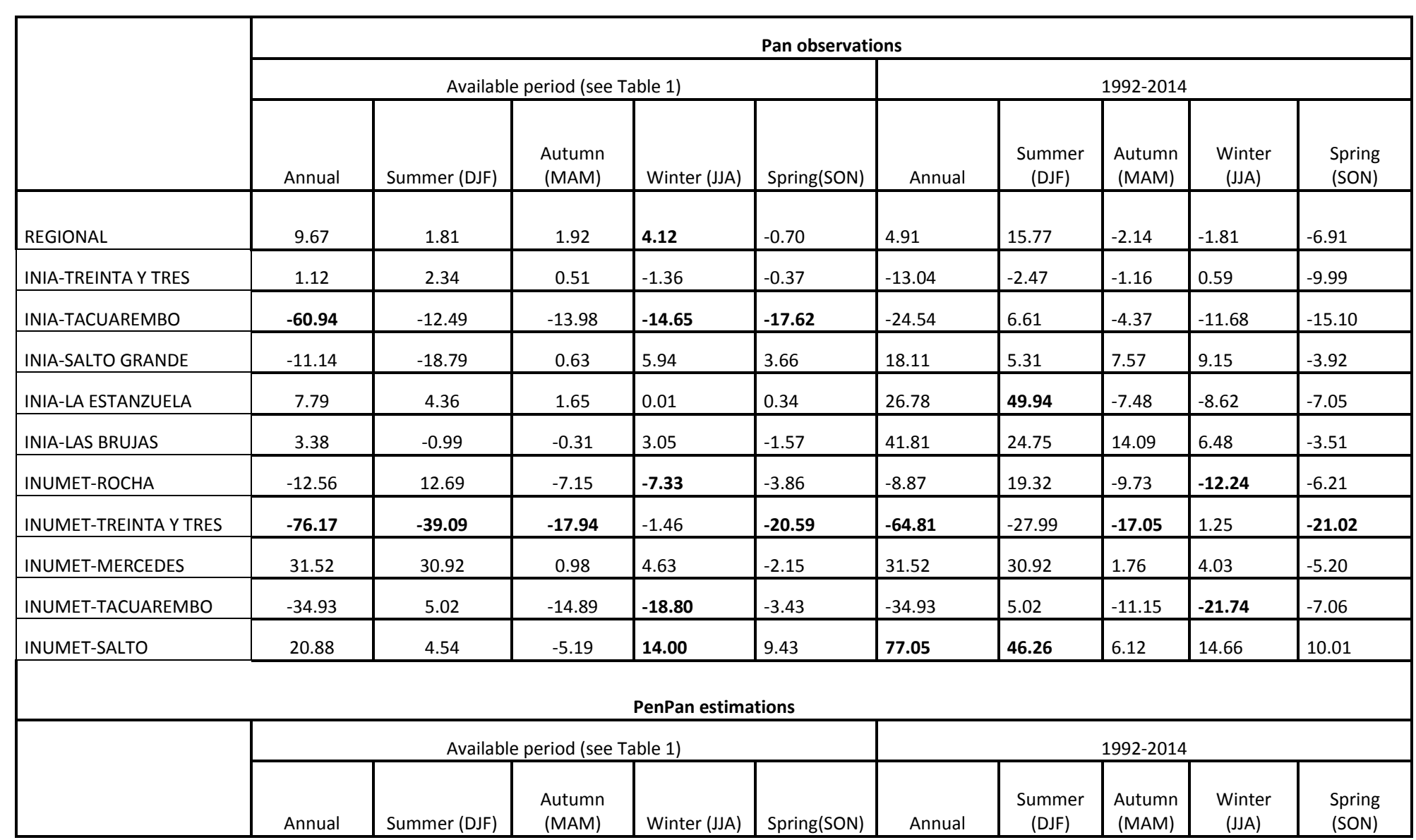




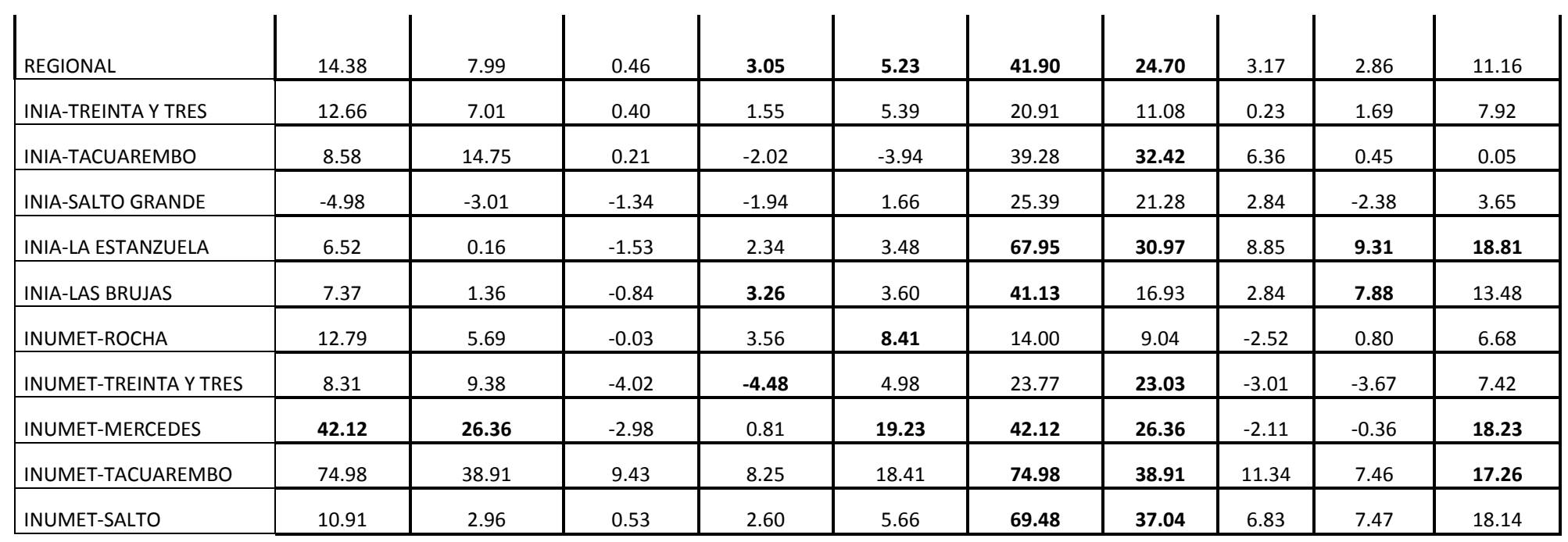


Table 4: Magnitude of change (per decade) of regional climate series for Uruguay from 1973 to 2014. Significant trends at $p<0.05$ are bolded.

\begin{tabular}{|l|c|c|c|c|c|}
\hline & Annual & $\begin{array}{c}\text { Summer } \\
(\mathrm{DJF})\end{array}$ & $\begin{array}{c}\text { Autumn } \\
(\mathrm{MAM})\end{array}$ & $\begin{array}{c}\text { Winter } \\
(\mathrm{JJA})\end{array}$ & $\begin{array}{c}\text { Spring } \\
(\mathrm{SON})\end{array}$ \\
\hline Max. Temp. $\left({ }^{\circ} \mathrm{C}\right)$ & 0.06 & 0.09 & -0.06 & 0.06 & $\mathbf{0 . 1 5}$ \\
\hline Min. Temp. $\left({ }^{\circ} \mathrm{C}\right)$ & $\mathbf{0 . 1 5}$ & 0.16 & 0.10 & 0.01 & $\mathbf{0 . 3 3}$ \\
\hline Wind speed $\left(\mathrm{ms}^{-1)}\right.$ & 0.00 & 0.01 & -0.01 & -0.02 & 0.01 \\
\hline $\begin{array}{l}\text { Relative Humidity } \\
(\%)\end{array}$ & -0.10 & $-\mathbf{0 . 3 8}$ & 0.00 & -0.17 & 0.19 \\
\hline $\begin{array}{l}\text { Sunshine duration } \\
\text { (hours) }\end{array}$ & -0.01 & 0.04 & -0.03 & 0.01 & -0.09 \\
\hline
\end{tabular}


Table 5. Correlations between seasonal and annual regional series of Pan observations and the series of the different meteorological variables. Significant correlations at $\mathrm{p}<$ 0.05 are bolded.

\begin{tabular}{|c|c|c|c|c|c|c|c|c|c|c|}
\hline & \begin{tabular}{|c|} 
INIA - \\
TREINTA \\
Y TRES \\
\end{tabular} & $\begin{array}{c}\text { INIA - } \\
\text { TACUAREMBO }\end{array}$ & \begin{tabular}{c|} 
INIA - \\
SALTO \\
GRANDE \\
\end{tabular} & $\begin{array}{c}\text { INIA - LA } \\
\text { ESTANZUELA }\end{array}$ & $\begin{array}{l}\text { INIA - } \\
\text { LAS } \\
\text { BRUJAS }\end{array}$ & $\begin{array}{l}\text { INUMET- } \\
\text { ROCHA }\end{array}$ & \begin{tabular}{|c|} 
INIMET- \\
TREINTA \\
Y TRES \\
\end{tabular} & $\begin{array}{l}\text { INUMET - } \\
\text { MERCEDES }\end{array}$ & $\begin{array}{c}\text { INUMET - } \\
\text { TACUAREMBO } \\
\end{array}$ & INUMET- SALTO \\
\hline & \multicolumn{10}{|c|}{ Maximum air temperature } \\
\hline Annual & 0.48 & 0.50 & 0.68 & 0.48 & 0.40 & 0.39 & 0.39 & 0.72 & 0.49 & 0.73 \\
\hline Summer (DJF) & 0.67 & 0.70 & 0.83 & 0.69 & 0.69 & 0.69 & 0.67 & 0.73 & 0.69 & 0.89 \\
\hline Autumn (MAM) & 0.59 & 0.69 & 0.79 & 0.40 & 0.41 & 0.53 & 0.61 & 0.84 & 0.68 & 0.70 \\
\hline Winter (JJA) & 0.47 & 0.38 & 0.33 & 0.19 & 0.11 & -0.17 & 0.16 & 0.29 & 0.42 & 0.55 \\
\hline \multirow[t]{2}{*}{ Spring (SON) } & 0.30 & 0.16 & 0.55 & 0.49 & 0.25 & 0.00 & -0.08 & 0.62 & 0.20 & 0.52 \\
\hline & \multicolumn{10}{|c|}{ Minimum air temperature } \\
\hline Annual & -0.41 & -0.37 & -0.23 & -0.10 & -0.32 & -0.20 & -0.28 & -0.19 & -0.34 & -0.13 \\
\hline Summer (DJF) & -0.47 & -0.18 & 0.08 & 0.26 & 0.10 & -0.08 & -0.37 & 0.07 & -0.20 & 0.11 \\
\hline Autumn (MAM) & -0.32 & -0.27 & -0.46 & -0.10 & -0.23 & -0.26 & -0.26 & -0.30 & -0.35 & -0.38 \\
\hline Winter (JJA) & -0.02 & -0.01 & -0.27 & -0.23 & -0.27 & -0.27 & 0.05 & -0.11 & 0.19 & 0.09 \\
\hline \multirow[t]{2}{*}{ Spring (SON) } & -0.54 & -0.59 & -0.42 & -0.14 & -0.44 & -0.67 & -0.59 & -0.17 & -0.74 & -0.44 \\
\hline & \multicolumn{10}{|c|}{ Wind speed } \\
\hline Annual & 0.40 & 0.17 & 0.26 & -0.02 & 0.42 & 0.20 & 0.32 & -0.59 & 0.07 & 0.38 \\
\hline Summer (DJF) & 0.55 & 0.27 & 0.30 & 0.60 & 0.54 & 0.33 & 0.24 & 0.24 & 0.25 & 0.20 \\
\hline Autumn (MAM) & 0.15 & 0.07 & -0.37 & 0.01 & 0.52 & 0.24 & 0.23 & -0.32 & -0.09 & -0.06 \\
\hline Winter (JJA) & 0.19 & 0.15 & -0.02 & -0.03 & 0.19 & 0.15 & 0.12 & -0.40 & -0.30 & 0.10 \\
\hline \multirow[t]{2}{*}{ Spring (SON) } & 0.04 & -0.02 & -0.09 & -0.06 & 0.26 & -0.07 & -0.05 & -0.61 & -0.02 & 0.07 \\
\hline & \multicolumn{10}{|c|}{ Relative Humidity } \\
\hline Annual & -0.64 & -0.85 & -0.76 & -0.67 & -0.57 & -0.35 & -0.40 & -0.60 & -0.67 & -0.73 \\
\hline Summer (DJF) & -0.83 & -0.88 & -0.86 & -0.80 & -0.62 & -0.70 & -0.57 & -0.75 & -0.81 & -0.92 \\
\hline Autumn (MAM) & -0.42 & -0.80 & -0.86 & -0.67 & -0.30 & -0.24 & -0.53 & -0.71 & -0.72 & -0.79 \\
\hline Winter (JJA) & -0.40 & -0.71 & -0.68 & -0.65 & -0.64 & -0.28 & -0.18 & -0.11 & -0.20 & -0.47 \\
\hline \multirow[t]{2}{*}{ Spring (SON) } & -0.70 & -0.72 & -0.62 & -0.62 & -0.62 & -0.40 & -0.52 & -0.68 & -0.62 & -0.71 \\
\hline & \multicolumn{10}{|c|}{ Sunshine Duration } \\
\hline Annual & 0.63 & 0.75 & 0.84 & 0.65 & 0.68 & 0.66 & 0.40 & 0.76 & 0.69 & 0.82 \\
\hline Summer (DJF) & 0.71 & 0.62 & 0.71 & 0.58 & 0.59 & 0.62 & 0.63 & 0.50 & 0.60 & 0.76 \\
\hline Autumn (MAM) & 0.63 & 0.69 & 0.85 & 0.61 & 0.60 & 0.53 & 0.41 & 0.85 & 0.62 & 0.78 \\
\hline Winter (JJA) & 0.33 & 0.37 & 0.64 & 0.51 & 0.41 & 0.38 & 0.31 & 0.38 & 0.27 & 0.52 \\
\hline Spring (SON) & 0.77 & 0.79 & 0.77 & 0.71 & 0.75 & 0.90 & 0.76 & 0.50 & 0.79 & 0.72 \\
\hline
\end{tabular}


Table 6. Correlations between seasonal and annual regional series of PenPan estimations and the series of the different meteorological variables. Significant correlations at $\mathrm{p}<0.05$ are bolded.

\begin{tabular}{|c|c|c|c|c|c|c|c|c|c|c|}
\hline & $\begin{array}{c}\text { INIA - } \\
\text { TREINTA } \\
\text { Y TRES } \\
\end{array}$ & $\begin{array}{c}\text { INIA - } \\
\text { TACUAREMBO }\end{array}$ & $\begin{array}{c}\text { INIA - } \\
\text { SALTO } \\
\text { GRANDE }\end{array}$ & $\begin{array}{c}\text { INIA - LA } \\
\text { ESTANZUELA }\end{array}$ & $\begin{array}{c}\text { INIA - } \\
\text { LAS } \\
\text { BRUJAS } \\
\end{array}$ & $\begin{array}{c}\text { INUMET- } \\
\text { ROCHA }\end{array}$ & $\begin{array}{c}\text { INIMET- } \\
\text { TREINTA } \\
\text { Y TRES } \\
\end{array}$ & $\begin{array}{l}\text { INUMET - } \\
\text { MERCEDES }\end{array}$ & $\begin{array}{c}\text { INUMET - } \\
\text { TACUAREMBO }\end{array}$ & $\begin{array}{l}\text { INUMET- } \\
\text { SALTO }\end{array}$ \\
\hline & \multicolumn{10}{|c|}{ Maximum air temperature } \\
\hline Annual & 0.52 & 0.65 & 0.75 & 0.64 & 0.38 & 0.67 & 0.67 & 0.76 & 0.73 & 0.63 \\
\hline Summer (DJF) & 0.70 & 0.86 & 0.89 & 0.80 & 0.73 & 0.80 & 0.80 & 0.91 & 0.87 & 0.93 \\
\hline Autumn (MAM) & 0.60 & 0.72 & 0.85 & 0.59 & 0.48 & 0.67 & 0.82 & 0.87 & 0.75 & 0.61 \\
\hline Winter (JJA) & 0.59 & 0.54 & 0.47 & 0.50 & 0.50 & 0.43 & 0.56 & 0.67 & 0.49 & 0.30 \\
\hline \multirow[t]{2}{*}{ Spring (SON) } & 0.51 & 0.50 & 0.66 & 0.61 & 0.62 & 0.53 & 0.41 & 0.80 & 0.64 & 0.50 \\
\hline & \multicolumn{10}{|c|}{ Minimum air temperature } \\
\hline Annual & -0.34 & -0.31 & -0.12 & 0.06 & -0.21 & 0.06 & -0.26 & 0.13 & -0.22 & -0.17 \\
\hline Summer (DJF) & -0.32 & -0.02 & 0.18 & 0.31 & 0.18 & 0.04 & -0.20 & 0.27 & 0.01 & 0.32 \\
\hline Autumn (MAM) & -0.24 & -0.46 & -0.41 & 0.03 & -0.10 & -0.01 & -0.20 & -0.19 & -0.59 & -0.45 \\
\hline Winter (JJA) & 0.14 & 0.14 & 0.06 & 0.08 & 0.12 & -0.06 & 0.32 & 0.42 & 0.08 & -0.06 \\
\hline \multirow[t]{2}{*}{ Spring (SON) } & -0.28 & -0.44 & -0.24 & -0.08 & -0.14 & -0.18 & -0.22 & 0.04 & -0.29 & -0.33 \\
\hline & \multicolumn{10}{|c|}{ Wind speed } \\
\hline Annual & 0.58 & 0.41 & 0.38 & 0.17 & 0.50 & 0.24 & 0.05 & -0.25 & 0.63 & 0.68 \\
\hline Summer (DJF) & 0.62 & 0.42 & 0.37 & 0.58 & 0.58 & 0.46 & 0.22 & 0.45 & 0.51 & 0.51 \\
\hline Autumn (MAM) & 0.19 & 0.24 & -0.24 & 0.03 & 0.43 & 0.09 & 0.26 & -0.18 & 0.12 & 0.19 \\
\hline Winter (JJA) & 0.31 & 0.35 & 0.32 & 0.25 & 0.38 & 0.13 & 0.27 & 0.36 & 0.55 & 0.51 \\
\hline \multirow[t]{2}{*}{ Spring (SON) } & 0.46 & 0.22 & 0.07 & 0.21 & 0.43 & 0.35 & -0.14 & -0.14 & 0.40 & 0.51 \\
\hline & \multicolumn{10}{|c|}{ Relative Humidity } \\
\hline Annual & -0.75 & -0.85 & -0.85 & -0.89 & -0.84 & -0.69 & -0.78 & -0.82 & -0.91 & -0.83 \\
\hline Summer (DJF) & -0.87 & -0.91 & -0.93 & -0.89 & -0.84 & -0.71 & -0.89 & -0.87 & -0.89 & -0.89 \\
\hline Autumn (MAM) & -0.66 & -0.85 & -0.91 & -0.82 & -0.70 & -0.70 & -0.69 & -0.76 & -0.93 & -0.94 \\
\hline Winter (JJA) & -0.70 & -0.83 & -0.71 & -0.77 & -0.67 & -0.70 & -0.39 & -0.55 & -0.70 & -0.63 \\
\hline \multirow[t]{2}{*}{ Spring (SON) } & -0.68 & -0.83 & -0.82 & -0.88 & -0.76 & -0.72 & -0.89 & -0.88 & -0.81 & -0.79 \\
\hline & \multicolumn{10}{|c|}{ Sunshine Duration } \\
\hline Annual & 0.66 & 0.86 & 0.85 & 0.74 & 0.76 & 0.53 & 0.80 & 0.64 & 0.77 & 0.86 \\
\hline Summer (DJF) & 0.74 & 0.76 & 0.71 & 0.69 & 0.71 & 0.72 & 0.84 & 0.49 & 0.66 & 0.63 \\
\hline Autumn (MAM) & 0.64 & 0.85 & 0.90 & 0.76 & 0.73 & 0.72 & 0.70 & 0.80 & 0.86 & 0.90 \\
\hline Winter (JJA) & 0.44 & 0.56 & 0.55 & 0.62 & 0.55 & 0.64 & 0.20 & 0.04 & 0.51 & 0.62 \\
\hline Spring (SON) & 0.72 & 0.84 & 0.71 & 0.78 & 0.72 & 0.62 & 0.76 & 0.79 & 0.75 & 0.80 \\
\hline
\end{tabular}




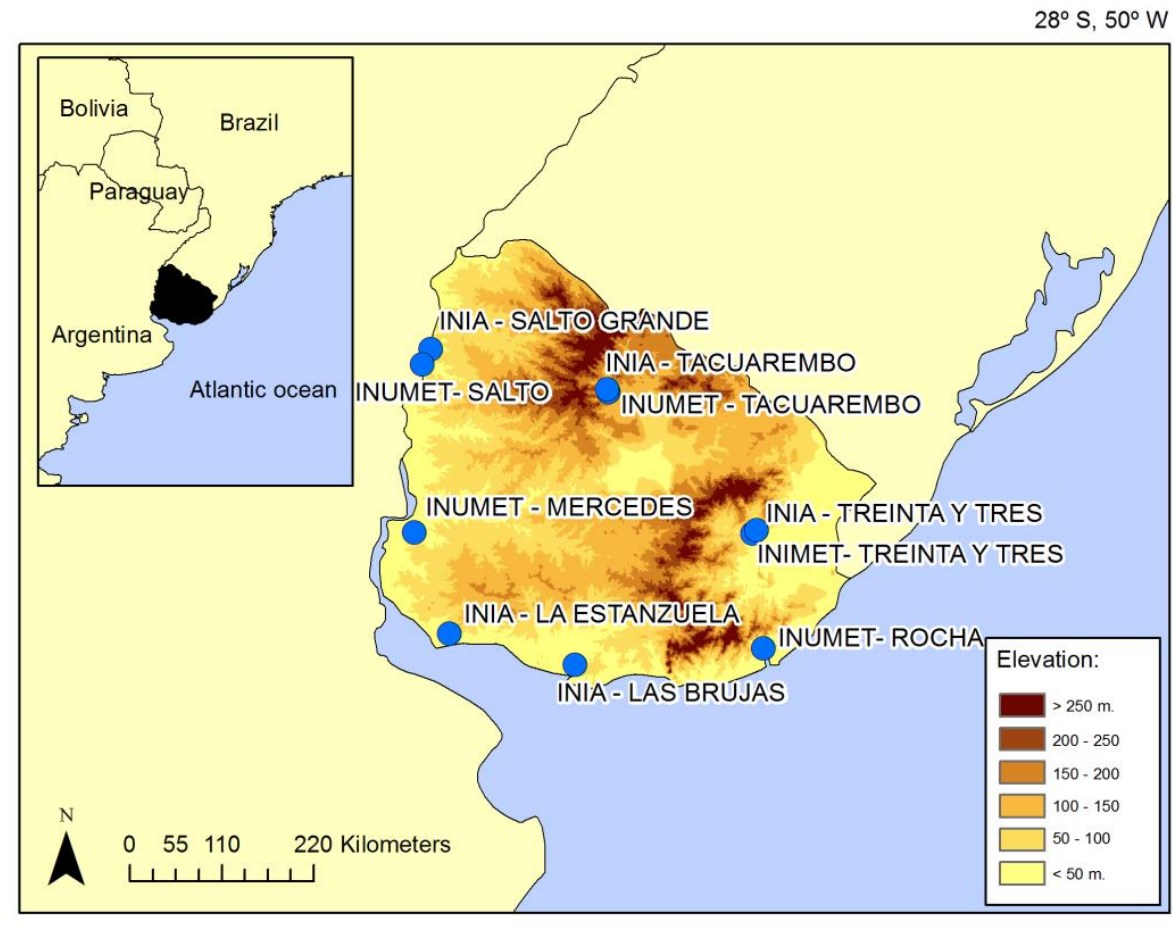

Figure 1: Topography and the spatial distribution of the meteorological stations (using a 'Network - Station' naming convention) used in this study. 
a)

Pan evaporation

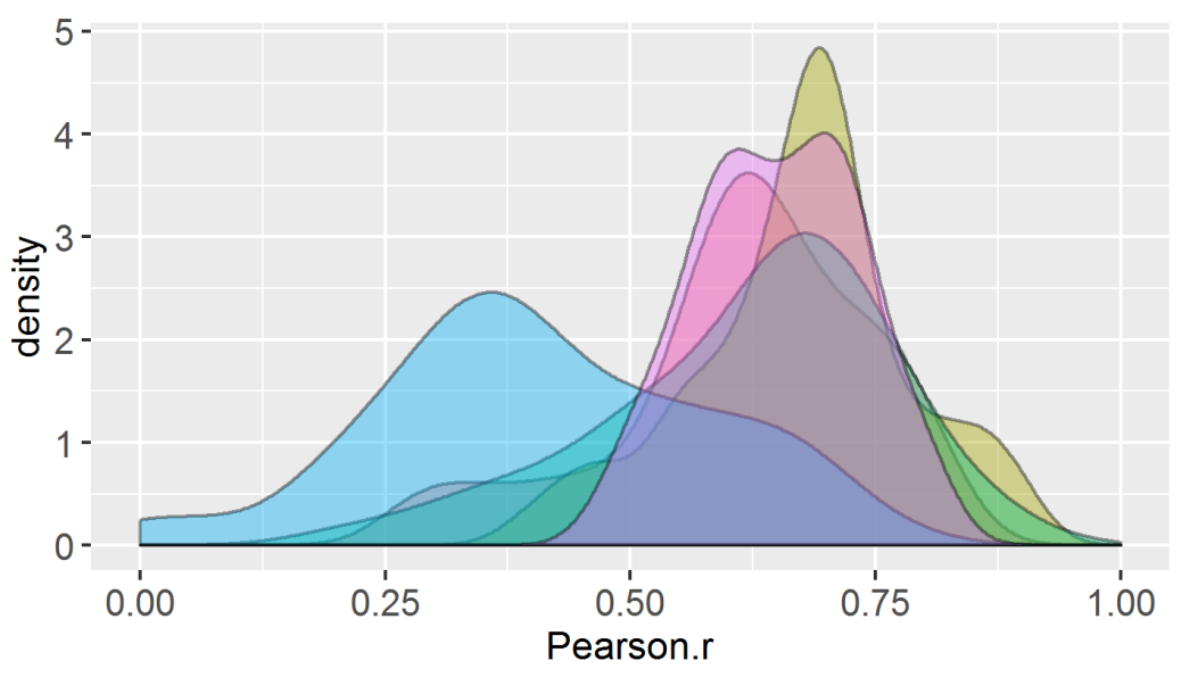

\section{Period}

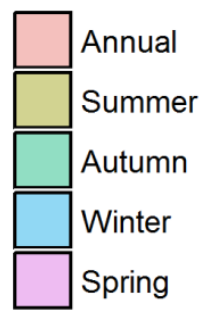

b)

PenPan
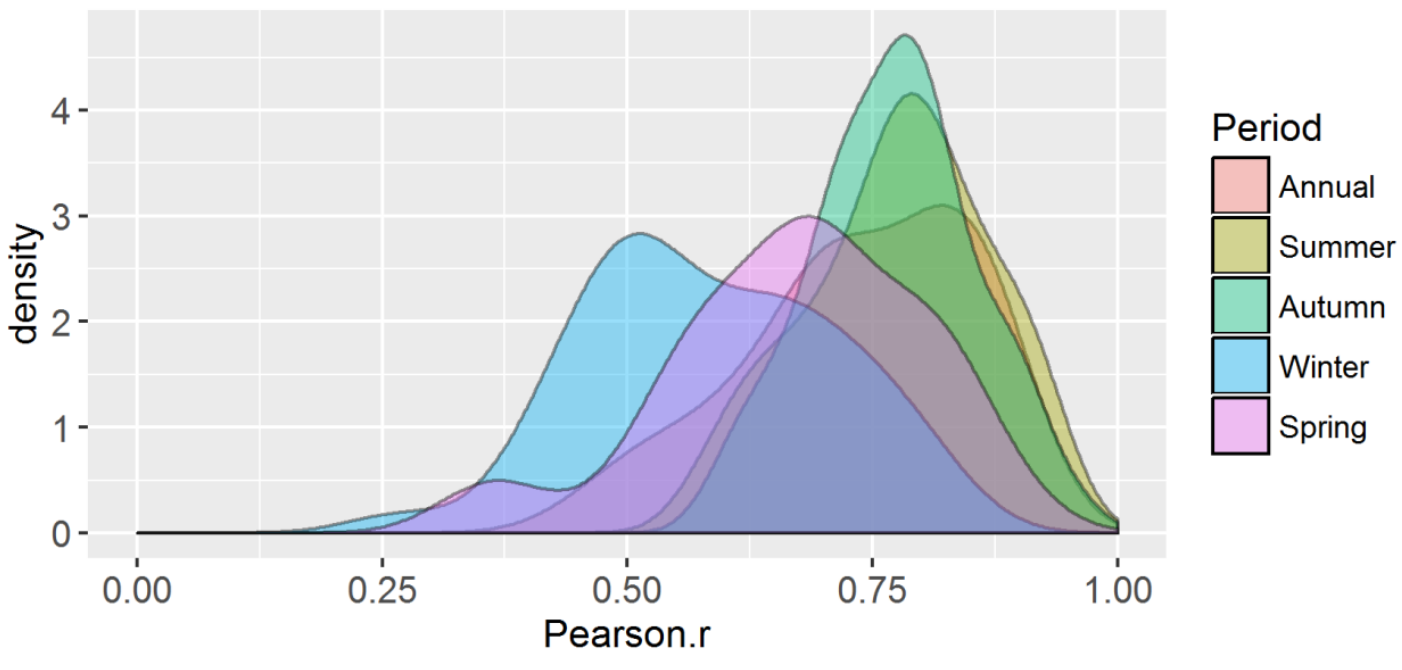

Figure 2: Density plots with the Pearson's r correlation coefficients calculated between a) Pan observations and b) PenPan estimations for all the different pairs of meteorological stations. 


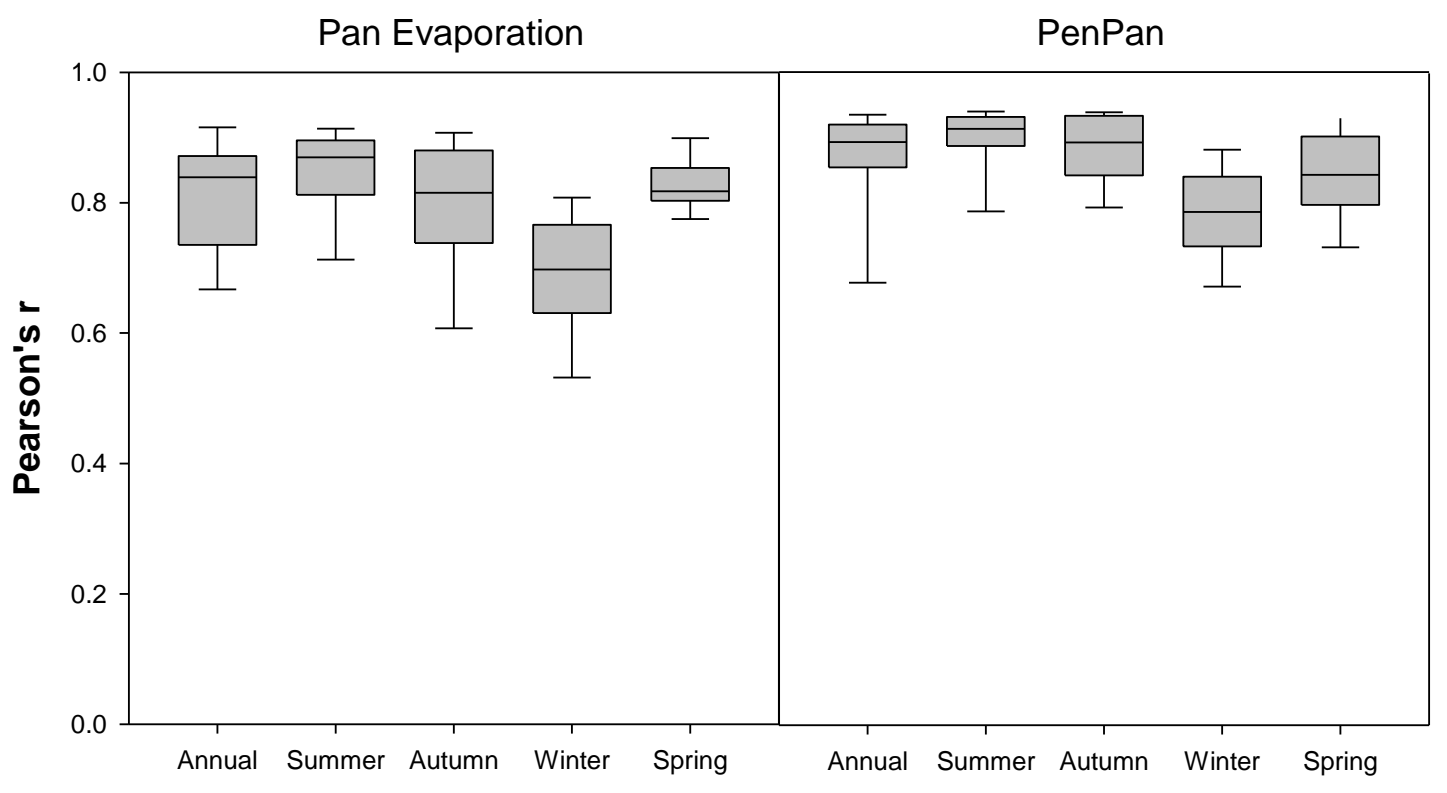

Figure 3: Box-whisker plot with the Pearson's r correlations between the time series of the individual stations and the regional series for the whole Uruguay. The central horizontal line shows the median, the shaded box is defined by the $25^{\text {th }}$ and $75^{\text {th }}$ percentiles, and the whiskers represent the $10^{\text {th }}$ and $90^{\text {th }}$ percentiles. 
a)

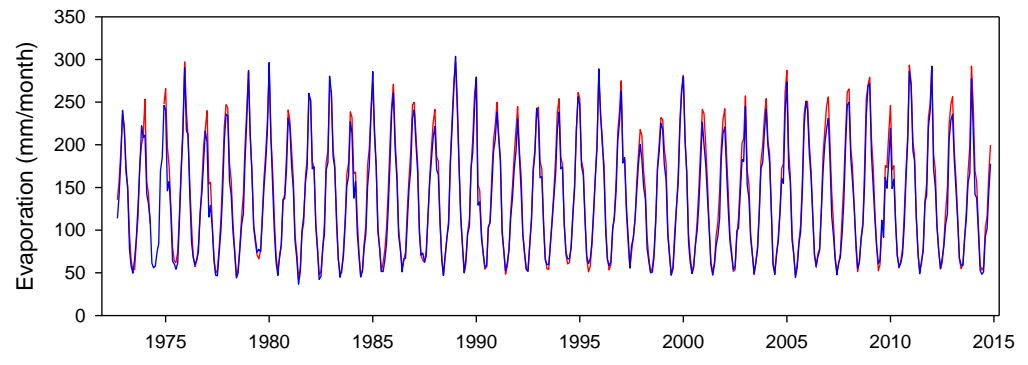

b)

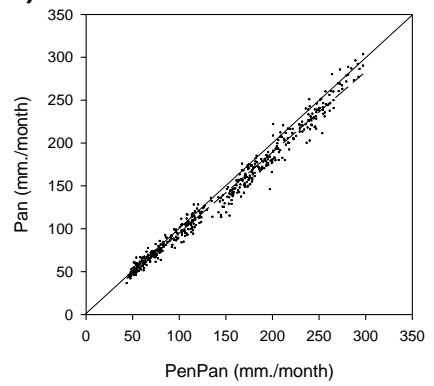

Figure 4: a) Temporal evolution of monthly values of Pan (Blue) observations and PenPan (Red) estimations calculated for the whole of Uruguay. b) Scatter plot showing the relationship between monthly values of Pan observations and PenPan estimations for the regional series. The dashed line in the right panel indicates the fitted regression line between Pan and PenPan and the black line is the 1:1 line. 

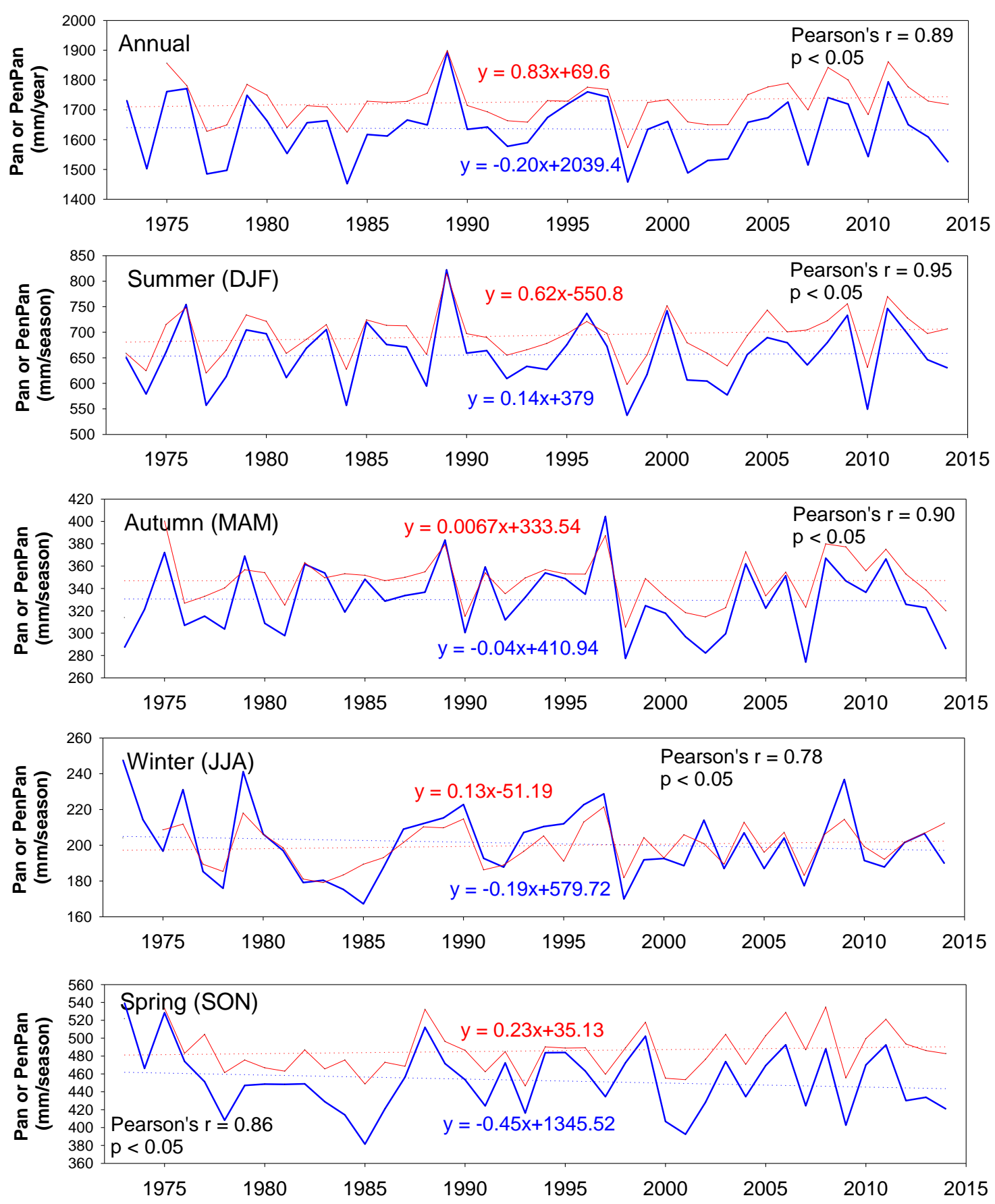

Figure 5: Seasonal and annual evolution of regional Pan (Blue) observations and PenPan (Red) estimations calculated for the whole of Uruguay. The Peason's $r$ value is between the Pand observations and PenPan estimations. The dotted lines correspond to the fitted regression of the series against time as the independent variable and the equations for each provided in the relevant colour. 

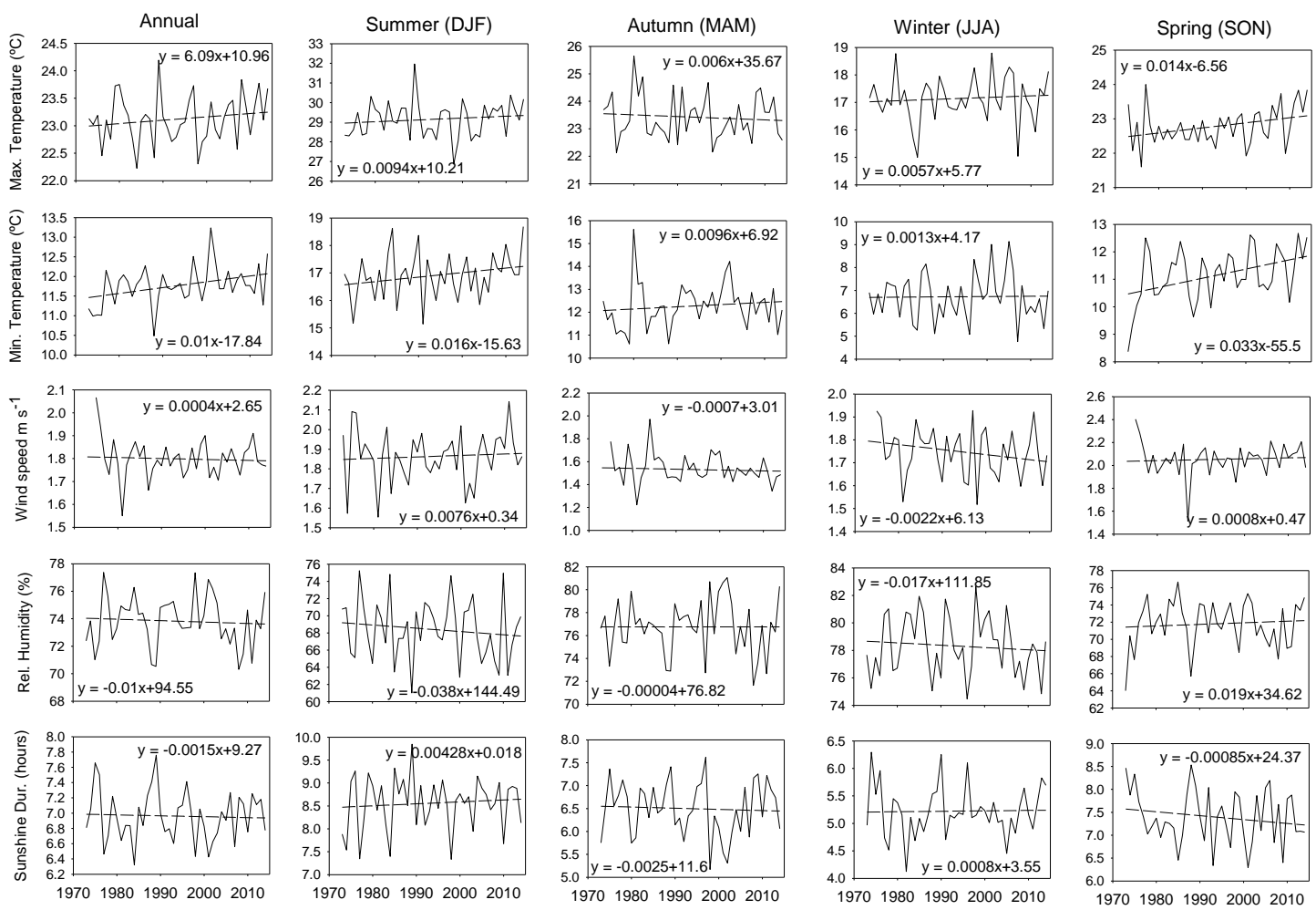

Figure 6: Seasonal and annual evolution of maximum and minimum air temperatures, wind speed at 2-m, relative humidity and sunshine duration for the nationwide regional series of Uruguay. Dashed lines correspond to the fitted regression of the series, and are defined by the equations shown on each subpart. 

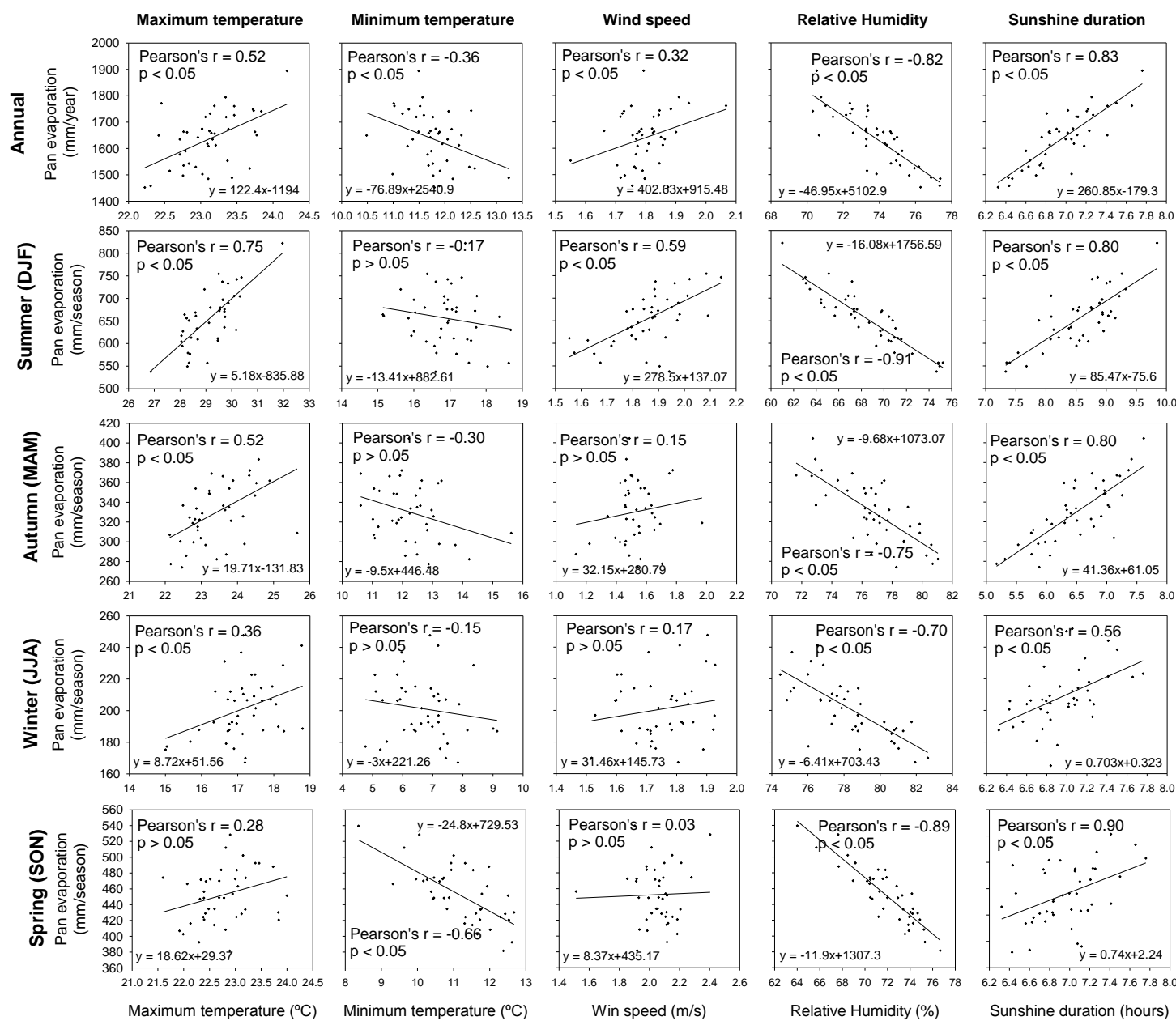

Figure 7: Relationship between seasonal and annual regional series of Pan observations and the series of the different meteorological variables. Solid lines correspond to the fitted regression of the series, and are defined by the equations shown on each subpart. 

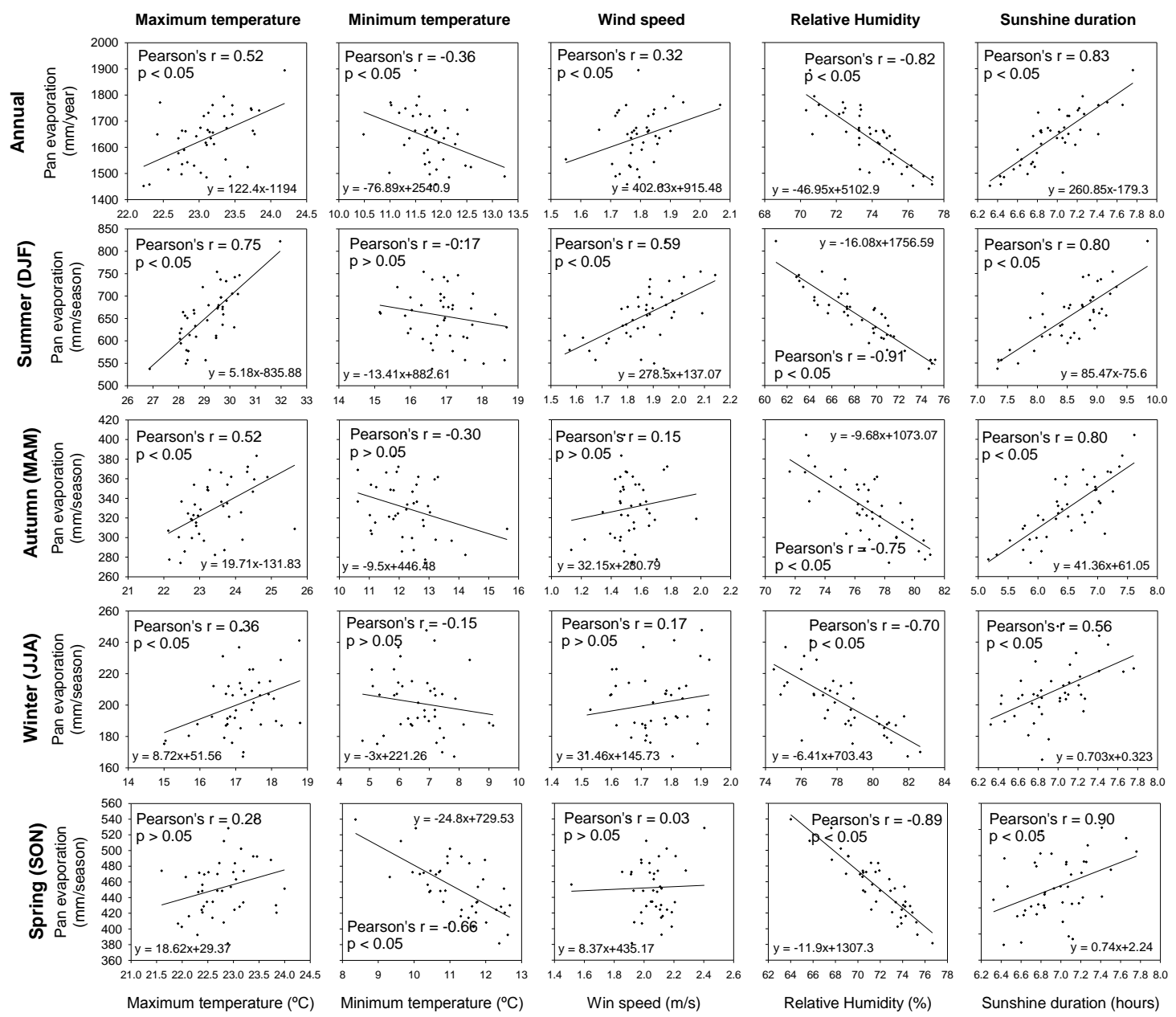

Figure 8: Relationship between seasonal and annual regional series of PenPan estimations and the series of the different meteorological variables. Solid lines correspond to the fitted regression of the series, and are defined by the equations shown on each subpart. 